\title{
Parthenogenetic bovine embryos secrete type I interferon capable of stimulating ISG15 in luteal cell culture
}

\author{
Alessandra Bridi, Kalyne Bertolin, Vitor B. Rissi, Lady K.S. Mujica, Werner G. Glanzner, \\ Mariana P. de Macedo, Fabio V. Comim, Paulo B.D. Gonçalves, Alfredo Q. Antoniazzi ${ }^{f}$
}

Laboratory of Biotechnology and Animal Reproduction - BioRep, Department of Large Animal Clinical Science, Federal University of Santa Maria, Santa Maria, RS, Brazil.

\begin{abstract}
Interferon tau (IFNT) is the pregnancy recognition signal in ruminants and is secreted by trophoblast cells. Paracrine action in the endometrium is well established by inhibiting luteolytic pulses of prostaglandin F2 alpha. Recently, endocrine action was documented in the corpus luteum, blood cell and liver. It was hypothesized that conditioned medium (CM) obtained from days 7, 9 and 12 parthenogenetic embryos alters luteal cell gene expression. The aim was to establish a bovine mixed luteal cell culture to evaluate cellular response associated to interferon stimulated genes, steroidogenesis and apoptosis. Conditioned medium was obtained from Days 7, 9 and 12 parthenogenetic (PA) embryos culture. Moreover, antiviral assay was performed on CM from Days 7, 9 and 12 to verify Type I interferon activity. Luteal cell culture was validated by steroidogenic and apoptotic genes (CYP11A1, HSD 3B1, $B A X, B C L 2, A K T$ and XIAP mRNA expression), and concentration of progesterone as endpoint. Luteal cell culture was treated with interferon alpha (IFNA) and CM from parthenogenetic embryos. Antiviral assay revealed Type I interferon activity on $\mathrm{CM}$ from embryos increasing on Days 9 and 12. ISG15 mRNA was greater in the mixed luteal cells culture treated with 1,10 and $100 \mathrm{ng} / \mathrm{ml}$ of interferon alpha (IFNA) and also on Days 7, 9 and $12 \mathrm{CM}$ treatments. Concentration of progesterone was not altered in luteal cell culture regardless of treatments. Steroidogenic and apoptotic genes were similar among groups in luteal cell culture treated with different doses of IFNA or CM from PA embryos. In conclusion, parthenogenetic embryo-derived $\mathrm{CM}$ has antiviral activity, luteal cell culture respond to Type I interferon by expressing IGS15. These data indicate this model can be used for IFNT endocrine signaling studies.
\end{abstract}

Keywords: ISG15, IFNT, luteal cell culture, IFNA, bovine

\section{Introduction}

Embryonic losses in early pregnancy result in premature return to estrus on dairy and beef cattle. In bovine, around $40 \%$ of embryo mortality occurs between Days 8 and 17 of pregnancy (Thatcher et al., 2001), corresponding to the period of interferon tau (IFNT) secretion by the trophectoderm, which characterizes the pregnancy recognition signal in ruminants (Imakawa et al., 1987). IFNT is a cytokine and acts in a paracrine manner inside the uterus by decreasing the expression of estrogen and oxytocin receptors in the uterine endometrium, and inhibiting the endometrial pulses of prostaglandin F2 alpha (PGF) to avoid luteolysis (Roberts et al., 2008). In addition to its antiluteolytic effects, IFNT increases the expression of interferon-stimulated genes (ISGs) in the endometrium (Austin et al., 2004), and in other extra uterine tissues such as blood (Han et al., 2006), liver and corpus luteum (CL) (Oliveira et al., 2008).

Recent studies support the hypothesis that the signal of maternal recognition of pregnancy also occurs in an endocrine manner in ruminants. In ewes, IFNT secreted by the conceptus reaches the uterine vein, inducing ISGs in the blood cells at early stages of pregnancy (Gifford et al., 2007; Oliveira et al., 2008; Bott et al., 2010). IFNT acts on extra uterine tissues through systemic circulation, reaching the $\mathrm{CL}$ and stimulating ISGs expression in luteal cells (Oliveira et al., 2008; Bott et al., 2010). Interferon-stimulated gene 15 (ISG15) is stimulated by Type 1 interferon (IFN), also called ubiquitin cross-reactive protein (Haas et al., 1987), and it is upregulated in endometrial cells of the mouse (Austin et al., 2003), human (Bebington et al., 1999) and ruminants (Austin et al., 1996) during early pregnancy. For this reason, ISG15 can be used as an indirect evidence of IFNT-dependent cellular response. IFNT binds to Type 1 interferon receptor (IFNAR1 and IFNAR2) to induce a response, and conjugates to intracellular proteins (Loeb and Haas, 1992) in a mechanism similar to ubiquitin (Narasimhan et al., 1996).

In ovine, ISG15 mRNA expression in large luteal cells is upregulated on Day 15 pregnant when compared to non-pregnant ewes. Moreover, IFNT concentrations were greater in uterine artery, uterine vein and jugular vein blood on Day 15 pregnant ewes (Oliveira et al., 2008). In another experiment, serum progesterone concentrations were maintained after PGF injection in IFNT-infused non-pregnant ewes for $24 \mathrm{~h}$ (Antoniazzi et al., 2013). Therefore, strong and recent evidences indicate that IFNT acting in an endocrine manner has an essential role during the initial period of pregnancy recognition in ruminants.

Studies involving IFNT signaling on extra uterine tissues started about ten years ago, and have been focused on in vivo models, whereas only few studies used in vitro models for this purpose. For this reason, our hypothesis is that conditioned medium (CM) from bovine parthenogenetic (PA) embryos have Type I IFN activity capable of modulating ISG15 mRNA expression in luteal cell culture. Consequently, the aim of this study was to establish a bovine luteal cell culture to evaluate its 
response when treated with $\mathrm{CM}$ on interferon stimulated genes (ISG15), steroidogenic (CYP11A1, HSD3B) and apoptotic ( $B A X, B C L 2, A K T$ and $X I A P)$ gene expression. Furthermore, this may be a potential method for studying endocrine signaling of IFNT

\section{Materials and Methods}

All experimental procedures used bovine ovaries from slaughterhouse, and were approved by the Animal Ethics and Use Committees (CEUA n ${ }^{\circ}$ 1563271115) at Federal University of Santa Maria.

\section{Oocyte retrieval and parthenogenetic activation}

Bovine ovaries, for embryo production, were obtained from the slaughterhouse and transported to the laboratory in a $0.9 \% \mathrm{NaCl}$ solution containing penicillin $(100 \mathrm{IU} / \mathrm{ml})$ and streptomycin sulfate $(50 \mu \mathrm{g} / \mathrm{ml})$ at $32^{\circ} \mathrm{C}$. Oocytes were aspirated from follicles $3-8 \mathrm{~mm}$ in diameter, and cultured for 22 to $24 \mathrm{~h}$, under $5 \% \mathrm{CO}_{2}$ in air at $38.5^{\circ} \mathrm{C}$, using TCM-199 (Gibco Labs, Waltham, MA, USA) supplemented with $10 \%$ fetal bovine serum (FBS), $5.0 \mathrm{mg} / \mathrm{ml}$ Luteinizing Hormone (LH), $0.5 \mathrm{mg} / \mathrm{ml}$ Follicle Stimulating Hormone (FSH) (Folltropin ${ }^{\circledR}-\mathrm{V}$, Bioniche, Ontario, CA, USA), $0.2 \mathrm{mM}$ pyruvate, $100 \mathrm{IU} / \mathrm{ml}$ of penicillin and $50 \mu \mathrm{g} / \mathrm{ml}$ of streptomycin. After in vitro maturation (IVM), oocytes were denuded by vortexing with hyaluronidase $(0.1 \%)$. Oocytes were washed four times in TCM-199, with $0.2 \%$ bovine serum albumin (BSA) and 100I U/ml of penicillin and $50 \mu \mathrm{g} / \mathrm{ml}$ of streptomycin before and after activation treatment. For the oocyte activation protocol, $5 \mu \mathrm{M}$ of ionomycin for $5 \mathrm{~min}$ was used. Then, oocytes were washed one more time and cultured in $2 \mathrm{mM}$ 6-dimethylaminopurine for $4 \mathrm{~h}$ (Méo et al., 2007). Finally, parthenogenetically activated oocytes were cultured in modified synthetic oviduct fluid (SOF) supplemented with 5\% FBS, $100 \mathrm{IU} / \mathrm{ml}$ of penicillin and $50 \mu \mathrm{g} / \mathrm{ml}$ of streptomycin under $5 \% \mathrm{CO}_{2}, 5 \% \mathrm{O}_{2}$ and, $90 \% \mathrm{~N}_{2}$ at $38.5^{\circ} \mathrm{C}$, up to Days 7,9 or 12 , when the conditioned medium (CM) was stored at $-80^{\circ} \mathrm{C}$ for subsequent usage. Cleavage was assessed $48 \mathrm{~h}$ after activation and the average rate was $79.6 \%$. Blastocyst development was observed on Day 7 after activation and the rates were about $38 \%$ over cleaved. The average number of embryos per group was 17 on Day 7, 14 on Day 9 and 3 embryos on Day 12.

\section{Corpus Luteum Dissociation and Cell Preparation}

Bovine ovaries were obtained from the slaughterhouse and transported to the laboratory in phosphate-buffered saline (PBS) containing penicillin $(100 \mathrm{IU} / \mathrm{ml})$ and streptomycin sulfate $(50 \mu \mathrm{g} / \mathrm{ml})$ at $4^{\circ} \mathrm{C}$ for corpus luteum in vitro culture. The CLs were classified as early (1-6 days post-ovulation), mid (8-12 days postovulation), and late (15-17 days post-ovulation) according to the criteria established by Miyamoto (Miyamoto et al., 2000). For this experiment, CLs were selected to be in early or mid estrous cycle, $15-25 \mathrm{~mm}$ in diameter; presenting luteal tissue on the ovarian surface; the color blood to pink, tan or orange; and compact soft consistency.

Luteal tissue was mechanically separated from its fibrous capsule, chopped into small pieces with scalpel blade, and further dissociated in a $0.1 \%$ collagenase Type IA (Sigma-Aldrich, St Louis, MO, USA), and DMEMF12 solution for $30 \mathrm{~min}$ at $37^{\circ} \mathrm{C}$. After, collagenase was inactivated with DMEM-F12 solution supplemented with $10 \%$ FBS, 1\% antibiotics (penicillin $10.000 \mathrm{IU} / \mathrm{ml}$ and streptomycin $10.000 \mu \mathrm{g} / \mathrm{ml}$ ). Cell suspension was washed and centrifuged twice for $10 \mathrm{~min}$ at $200 \mathrm{Xg}$ with DMEMF12 solution supplemented with $10 \%$ FBS, 1\% antibiotics. Then, luteal cells were plated on $60 \mathrm{~mm}$ dishes for $48 \mathrm{~h}$ at $37^{\circ} \mathrm{C}$ in $5 \% \mathrm{CO}_{2}$. After $48 \mathrm{~h}$ culture, the medium was changed. The viability of the luteal cells was assessed by the Trypan Blue (Sigma-Aldrich, St Louis, MO, USA) when the cells were trypsinized, and then they were seeded again in 96-well plates at $3 \times 10^{4}$ cells/well. For cell culture adaptation, luteal cells were cultured in SOF supplemented with $5 \% \mathrm{FBS}, 100 \mathrm{IU} / \mathrm{ml}$ of penicillin and $50 \mu \mathrm{g} / \mathrm{ml}$ of streptomycin for $12 \mathrm{~h}$. Next, the cells received treatments as detailed in the experimental design 1 and 2.

Concentrations of progesterone in luteal cell culture media

Concentration of progesterone was determined by chemiluminescence kit (ADVIA Centaur, Siemens). The sensitivity of the assay was $0.15 \mathrm{ng} / \mathrm{ml}$. Progesterone concentration was measured on $\mathrm{CM}$ from luteal cell culture following experimental design.

\section{$R N A$ extraction, reverse transcription and real-time PCR}

Extraction of RNA from luteal cell culture was performed using TRIzol ${ }^{\circledR}$. Quantification and estimation of RNA purity was performed using a Nano-Drop spectrophotometer (Thermo Scientific - Waltham USA; Absorbance 260/280 nm ratio). RNA was treated with 0.1 U DNase Amplification Grade (Invitrogen) for $15 \mathrm{~min}$ at $27^{\circ} \mathrm{C}$, to digest any contaminating DNA. After, DNase was inactivated by adding $1 \mathrm{ul}$ of EDTA at $65^{\circ} \mathrm{C}$ for $10 \mathrm{~min}$. Single-stranded cDNA was synthesized from $1000 \mathrm{ng}$ of total RNA with final volume of $20 \mathrm{ul}$ using iScript cDNA Synthesis Kit (BioRad, Hercules, CA) according to the manufacturer's instructions. Quantitative polymerase chain reactions (qPCR) were conducted in a CFX384 thermocycler (BioRad) using a final volume of $10 \mathrm{ul}$ per well using BRYT Green ${ }^{\circledR}$ dye and Taq DNA polymerase from GoTaq ${ }^{\circledR}$ qPCR Master Mix (Promega Corporation), with cDNA (2 ul) and bovine-specific primers (Tab. 1). Amplification was performed with initial denaturation at $95^{\circ} \mathrm{C}$ for 5 min followed by 40 cycles of denaturation at $95^{\circ} \mathrm{C}$ for $15 \mathrm{sec}$ and annealing/extension at $60^{\circ} \mathrm{C}$ for $30 \mathrm{sec}$.

To optimize the qPCR assay, serial dilutions of cDNA templates were used to generate a standard curve. The standard curve was constructed by plotting the log of the starting quantity of the dilution factor against the $\mathrm{Ct}$ 
value obtained during amplification of each dilution. Reactions with a coefficient of determination $\left(\mathrm{R}^{2}\right)$ higher than 0.98 and efficiency between 85 to $110 \%$ were considered optimized. The relative standard curve method was used to assess the amount of a particular transcript in each sample. Samples were run in duplicate and results are expressed relative to GAPDH and RPL19. The target genes are presented on Table1.

Table 1. Real time qPCR primer sequences.

\begin{tabular}{|c|c|c|}
\hline Target & Accession & Primers sequences \\
\hline$G A P D H$ & NM_001034034.2 & $\begin{array}{l}\text { F tgaccccttcattgaccttc } \\
\text { R cgttctctgccttgactgtg }\end{array}$ \\
\hline RPL19 & NM_001040516.1 & $\begin{array}{l}\text { F ccggctgcttagacgatacc } \\
\text { R ccgcttgtttttgaacacgtt }\end{array}$ \\
\hline$I S G 15$ & NM_174366 & $\begin{array}{l}\text { F ggtatccgagctgaagcagtt } \\
\mathrm{R} \text { acctccctgctgtcaaggt }\end{array}$ \\
\hline$B A X$ & NM_173894 & $\begin{array}{l}\text { F ttctgacggcaacttcaact } \\
\text { R cgaaggaagtccaatgtcca }\end{array}$ \\
\hline$B C L 2$ & NM_001166486.1 & $\begin{array}{l}\text { F cctatctgggccataagtgaag } \\
\text { R gtggtgcatcagcaacaatg }\end{array}$ \\
\hline$A K T$ & NM_173986.2 & $\begin{array}{l}\text { F gattcttcgccagcatcgtg } \\
\text { R ggccgtgaactcctcatcaa }\end{array}$ \\
\hline$X I A P$ & NM_001205592.1 & $\begin{array}{l}\text { F gaagcacggatcattacatttgg } \\
\text { R ttcacctaaagcataaaatccag }\end{array}$ \\
\hline CYP11A1 & NM_176644.2 & $\begin{array}{l}\text { F cttgcaccttctggctagg } \\
\text { R aaggggaagaggtagggtga }\end{array}$ \\
\hline$H S D 3 B 1$ & NM_174343.3 & $\begin{array}{l}\text { F gcccaactcctacagggagat } \\
\text { R ttcagagcccacccattagct }\end{array}$ \\
\hline
\end{tabular}

$\mathrm{F}$, forward; $\mathrm{R}$, reverse.

\section{Interferon-induced antiviral activity assay}

Interferon-induced antiviral activity of the samples were determined based on a modified antiviral assay (Vogel et al., 2001). Madin-Darby bovine kidney cells (MDBK) were used for amplification and titration of vesicular stomatitis virus, and for IFN-induced antiviral activity assay. Briefly, samples and IFN control (100 IU of IFNA) were diluted in base 2 (4 to 2048) in 96-well plate and a suspension of MDBK cells was added. The plate was maintained in $\mathrm{CO}_{2}$ atmosphere for $12-18 \mathrm{~h}$, at $37^{\circ} \mathrm{C}$. Vesicular stomatitis virus were inoculated at 100 tissue culture infectious doses $\left(\mathrm{TCID}_{50}\right)$ in all dilutions of the samples, IFN and virus control. The dishes were maintained in $\mathrm{CO}_{2}$ atmosphere, for $24 \mathrm{~h}$, at $37^{\circ} \mathrm{C}$. The first well in the dilution series of a sample that exhibits cytopathic effect equivalent to that of the virus control wells was defined as the endpoint. Title samples were established based on IFNA control.

\section{Experimental design}

Experiment 1: Validation of bovine luteal cell culture viability and IFNA responsiveness

This study evaluated the dose-dependent response in luteal cell culture treated with IFNA. Relative ISG15 mRNA expression, steroidogenic genes $(C Y P 11 A 1, H S D 3 B 1)$, and apoptosis related genes $(B A X$, $B C L 2, A K T$ and $X I A P)$ were assessed in order to validate this model. For this, luteal cells were treated in vitro for $24 \mathrm{~h}$ with 0 (SOF), $0.1,1,10$, or $100 \mathrm{ng} / \mathrm{ml}$ of IFNA (IFN 2 alpha - ROCHE). Following treatment, cells were washed with PBS and collected using TRIzol ${ }^{\circledR}$, and stored at $-80^{\circ} \mathrm{C}$ for subsequent RNA extraction. In the culture medium, P4 concentration was measured in control, and on groups treated with 1 and $100 \mathrm{ng} / \mathrm{ml}$ of IFNA. The experiment was repeated four times, and each replicate used 5 different CLs as previously stated.

Experiment 2: Exposure of bovine luteal cell to conditioned medium derived from parthenogenetic embryos

After validating luteal cell culture responsiveness to IFNA, the aim of the second experiment was to verify whether mixed luteal cell culture respond similarly to $\mathrm{CM}$ from parthenogenetic activated embryos cultured for 7,9 or 12 Days. Luteal cells were treated for $24 \mathrm{~h}$ with SOF (control; without embryos) and conditioned medium from parthenogenetic activated embryos (CM) collected on Days 7, 9 and 12 of the embryonic development. Subsequently, luteal cells were collected for RNA extraction as previously described. Interferon-induced antiviral activity was assessed in CM from embryos on Days 7, 9 and 12 to evaluate the bioactivity of Type I IFN. Concentration of progesterone was measured in pools of CM from embryos on days 7, 9 and 12 after $24 \mathrm{~h}$ of treatment. The experiment was performed in three replicates of parthenogenetic activated embryos and two replicates of luteal cell culture, $(n=5$ CLs per replicate).

\section{Statistical analysis}

All data were analyzed using JMP (Version 7.0 SAS Institute Inc.) statistical software. The mRNA expression data were analyzed using ANOVA and 
differences between treated and control luteal cell culture were compared by Tukey's test. All numerical data are represented as mean \pm SEM. Significant differences were considered at $\mathrm{P} \leq 0.05$.

\section{Results}

Viability of mixed luteal cells cultured in vitro and progesterone secretion in the culture medium

The viability of luteal cells ranged from $80 \%$ to $90 \%$ as evaluated by the Trypan Blue method for both IFNA and CM treated cells (data not shown). Concentration of progesterone was determined in the culture medium $24 \mathrm{~h}$ after luteal cells treatment with IFNA or CM (Tab. 2). IFNA and CM have no impact on progesterone productions. These data indicate that luteal cell cultured in vitro produce $\mathrm{P} 4$, validating the system. However, P4 production is not influenced by IFNA or CM.

\section{Antiviral assay of Type I IFN activity}

Conditioned medium presented antiviral activity compatible with Type I IFNs on Days 7, 9 and 12. Antiviral activity in the CM of PA embryos on Days 9 and 12 was greater $(\mathrm{P}<0.0001)$ than on Day 7 and control groups. The levels of Type I IFN activity ranged from 50 to $>200 \mathrm{UI} / \mathrm{ml}$ on $\mathrm{CM}$ (Fig. 1).

Interferon stimulated gene 15 (ISG15) mRNA expression in mixed luteal cell exposed to IFNA or CM

Relative ISG15 mRNA expression was evaluated on luteal cells culture treated for $24 \mathrm{~h}$ with different doses of IFNA (control, 0.1, 1, 10 or $100 \mathrm{ng} / \mathrm{ml}$ ) or CM on Days 7, 9 or 12. Luteal cells responded to $1 \mathrm{ng} / \mathrm{ml}$ of IFNA increasing ISG15 mRNA expression ( $\mathrm{P}<0.0001)$, at 10 and $100 \mathrm{ng} / \mathrm{ml}$ when compared to control (Fig. 2A). Subsequently, luteal cells treatment with $\mathrm{CM}$ from different embryonic developmental days (7, 9 and 12), increased $(\mathrm{P}=0.0001)$ ISG15 mRNA expression when compared to control group (Fig. 2B). Considering IFNA as positive control, both treatments (IFNA and CM) presented a similar ISG15 mRNA expression. These data indicate that luteal cells culture treated with CM from PA embryos can induce ISGI5 in a developmental dependent manner.

Expression pattern of steroidogenic and cell survival genes by bovine luteal cells in response to IFNA or conditioned medium derived from parthenogenetic embryos

Luteal cell culture was treated for $24 \mathrm{~h}$ with different doses of IFNA (control, 0.1, 1, 10 or $100 \mathrm{ng} / \mathrm{ml}$ ) to evaluate the expression of steroidogenic genes $(C Y P 11 A 1, H S D 3 B 1)$ and cell survival genes (BAX, $B C L 2, A K T$ and XIAP). The expression of CYP11A1 (Fig. $3 \mathrm{~A}$ ) and $H S D 3 B 1$ (Fig. 3B) was not different regardless of IFNA dose, indicating that IFNA does not regulate the transcription of steroidogenic genes, complementing the progesterone production data. Apoptosis/survival genes $B A X, B C L 2, A K T$ and XIAP mRNA were not affected by different concentrations of IFNA in luteal cell culture (Fig. 3C-F), These data suggest IFNA does not regulate the transcription of genes associated with cell survival, confirming luteal cell viability.

Relative mRNA expression of steroidogenic enzymes (CYP11A1, HSD3B1) and cell survival genes (BAX, BCL2, AKT and XIAP) were assessed on luteal cell culture treated for $24 \mathrm{~h}$ with $\mathrm{CM}$ from Days 7, 9 or 12 . CYP11A1 (Fig. 4A) and HSD3B1 (Fig. 4B) mRNA expression did not vary regardless of day of embryo culture when $\mathrm{CM}$ was obtained. For the cell survival genes, $B A X$ (Fig. 4C), BCL2 (Fig. 4D), $A K T$ (Fig. 4E) and $X I A P$ (Fig. 4F) mRNA expression was constant in all groups. Luteal cells treated with $\mathrm{CM}$ did not regulate mRNA levels of genes of steroidogenic enzymes, and cell survival genes. This data suggest CM from PA embryos do not regulate the transcription of genes associated with steroidogenesis and cell survival.

Table 2. Concentration of progesterone produced by luteal cells in culture at $24 \mathrm{~h}$ of treatment with IFNA or conditioned medium (CM) from parthenogenetic embryos.

\begin{tabular}{ll}
\multicolumn{1}{c}{ Luteal cells treatment } & P4 concentration $(\mathrm{ng} / \mathrm{ml})$ \\
\hline SOF (positive control) & 0.21 \\
PA embryo CM 7, 9 and 12 after $24 \mathrm{~h}$ treatment $-1^{\circ}$ replicate & 181.32 \\
PA embryo CM 7, 9 and 12 after $24 \mathrm{~h}$ treatment $-2^{\circ}$ replicate & 132.06 \\
Culture medium after $24 \mathrm{~h}$ treatment (control IFNA) & 145 \\
Culture medium after $24 \mathrm{~h}$ treatment $(1 \mathrm{ng} / \mathrm{ml}$ IFNA) & 192.60 \\
Culture medium after $24 \mathrm{~h}$ treatment $(100 \mathrm{ng} / \mathrm{ml}$ IFNA) & 184.12 \\
\hline
\end{tabular}




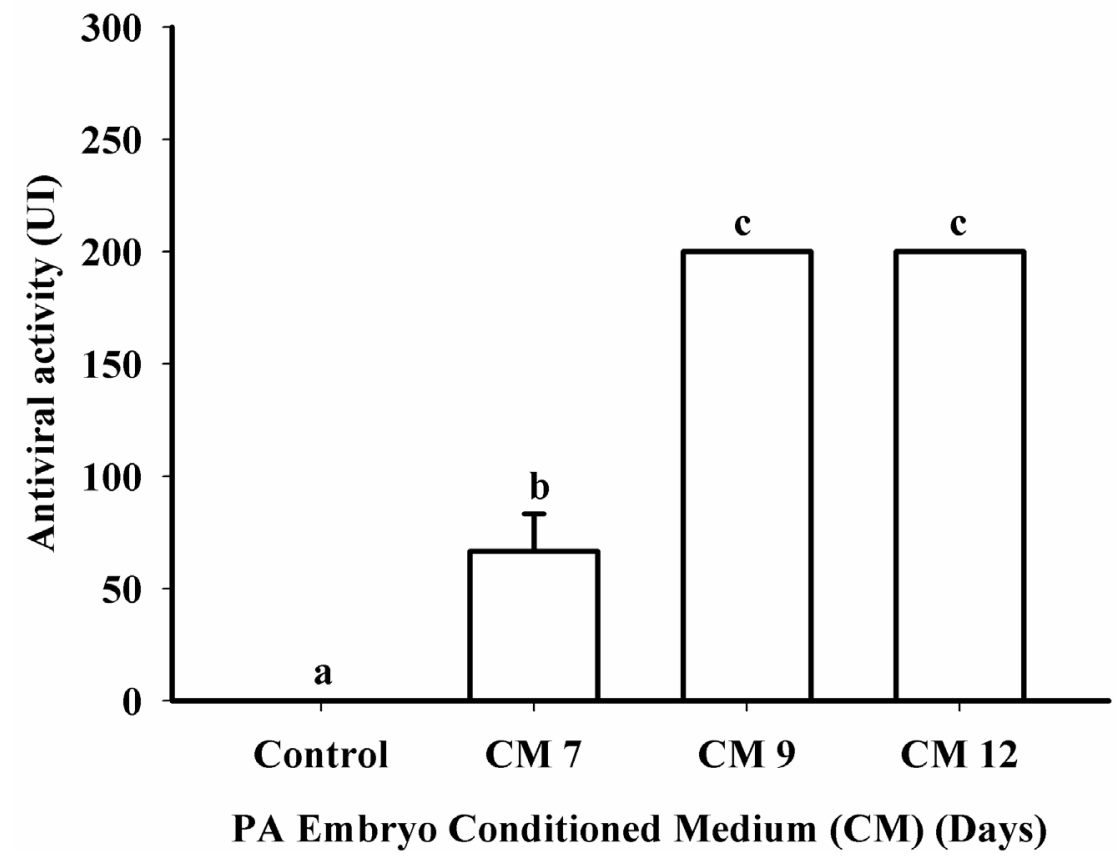

Figure 1. Antiviral activity (nontransformed data) detected in conditioned medium (CM) from parthenogenetic activated (PA) bovine embryos on Days 7, 9 or 12 of development. Antiviral activity from CM was detected on Days 7, 9 or 12 when compared to control (medium with no embryos). The levels of Type I IFN were 50 to $>200 \mathrm{UI} / \mathrm{ml}$ in the CM. Data are presented as mean \pm SEM and differences $(\mathrm{P}<0.05)$ are represented by different lowercase letters.
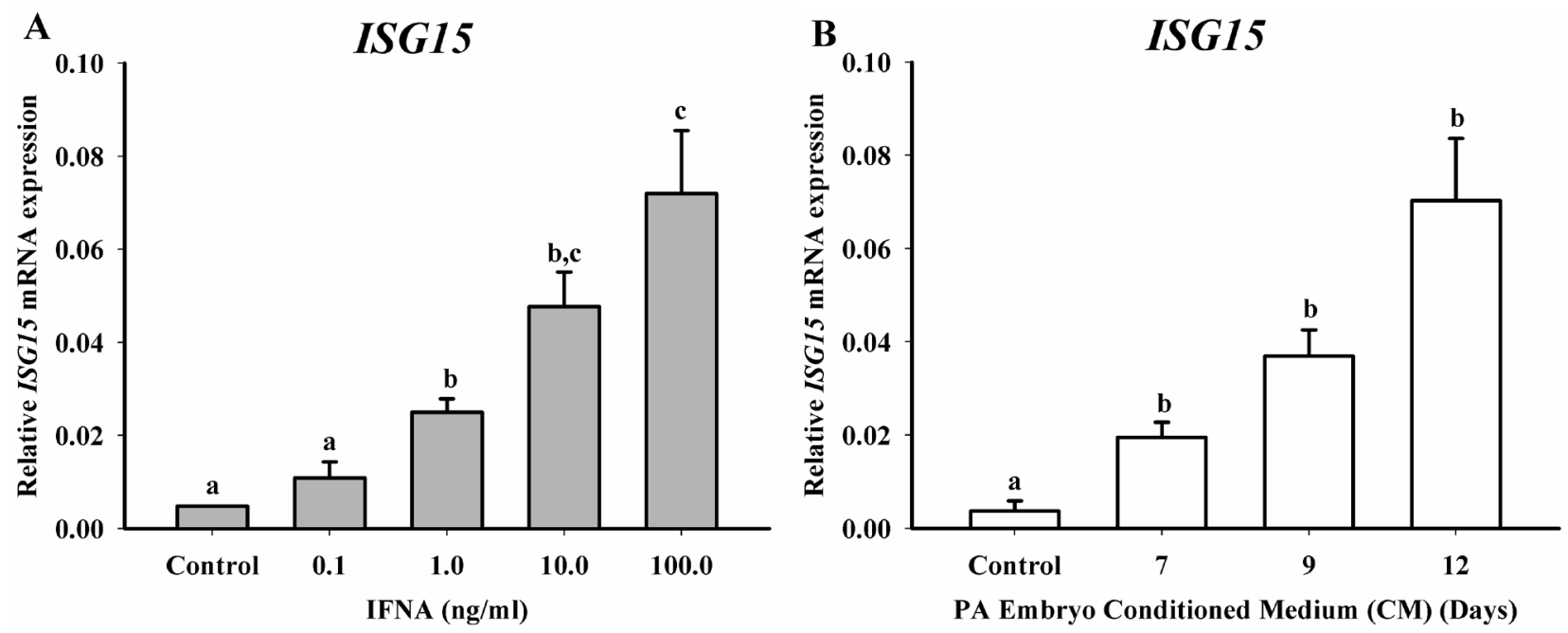

Figure 2. ISG15 mRNA expression in luteal cell culture following treatment with different concentrations of IFNA or conditioned medium (CM) from parthenogenetic activated (PA) embryos on Days 7, 9 or 12. (A) Relative ISG15 mRNA expression in luteal cells treated with control (medium with no embryos), 0.1, 1, 10 or $100 \mathrm{ng} / \mathrm{ml}$ of IFNA. Luteal cells increased ( $\mathrm{P}<0.0001$ ) ISG15 mRNA expression in a dose-dependent manner, responding to $1 \mathrm{ng} / \mathrm{ml}$. (B) Relative ISG15 mRNA expression in luteal cell culture after treatment with CM from PA embryos on Days 7, 9 or 12. ISG15 mRNA expression on Days 7, 9 and 12 were greater $(\mathrm{P}=0.0001)$ when compared to control. Data are presented as mean \pm SEM and differences $(\mathrm{P}<0.05)$ are indicated by different lowercase letters. 

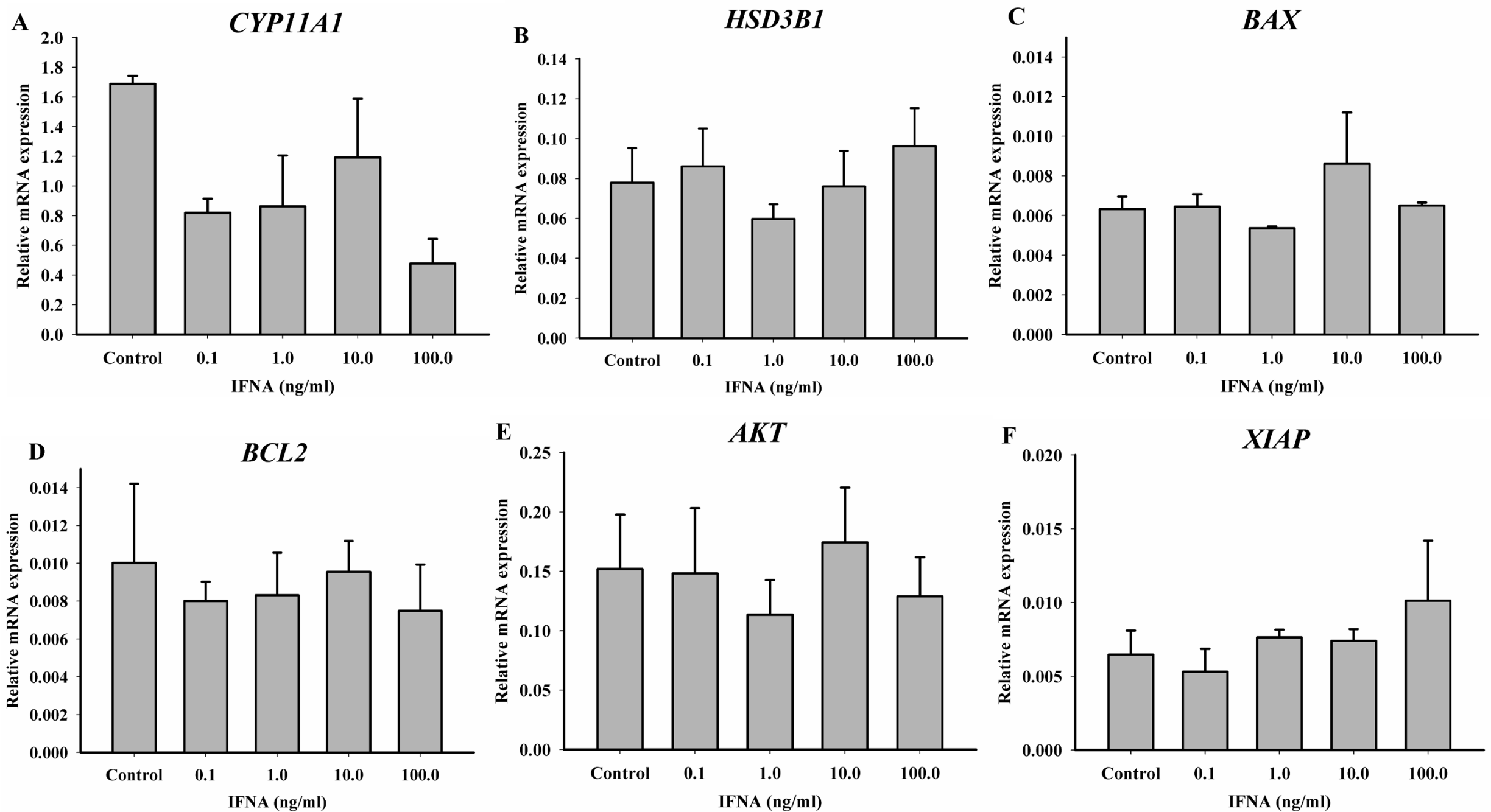

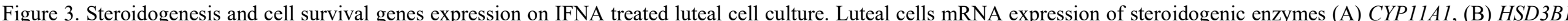

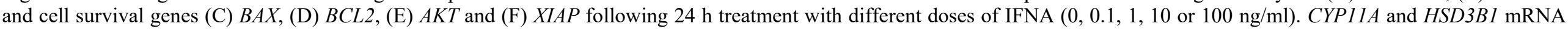

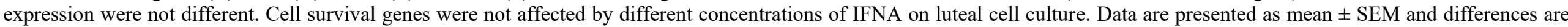
represented by different lowercase letters. 

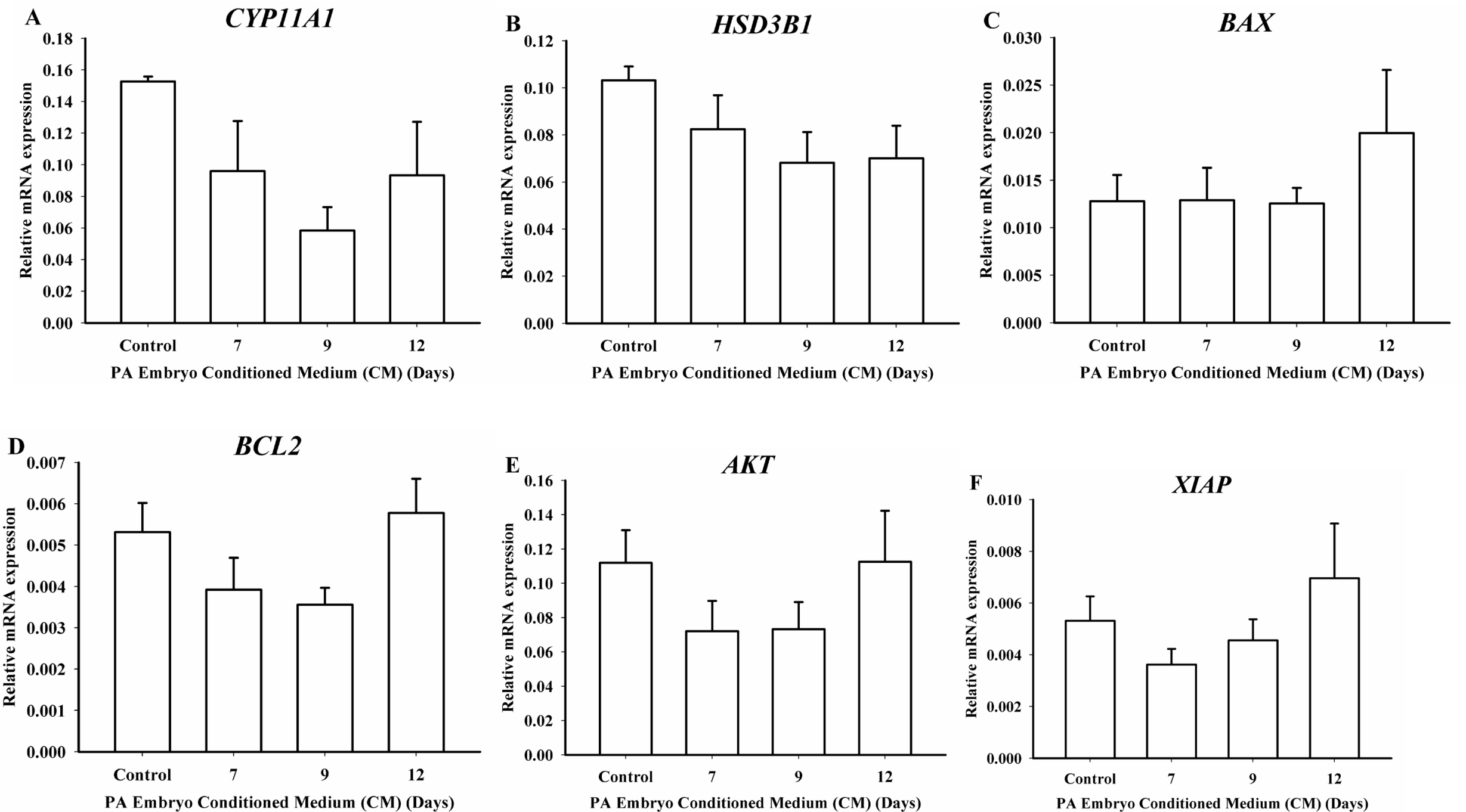

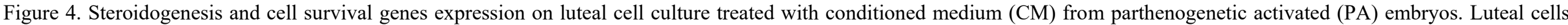

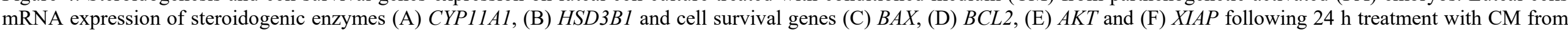

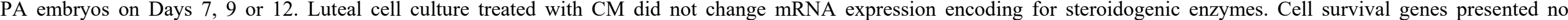
differences among groups. Data are presented as mean \pm SEM and differences are represented by different lowercase letters. 


\section{Discussion}

ISG15 is a protein expressed in the uterine endometrium on early pregnancy in response to the paracrine action of the embryo-derived IFNT in ruminants (Austin et al., 2004). The presence of ISG15 protein and mRNA on the CL of Day 15 pregnant ewes suggests the possible endocrine action of IFNT (Oliveira et al., 2008). The uterine vein infusion of IFNT extends luteal life span and protects the CL from PGF-induced luteolysis in ewes, further demonstrating the likely endocrine mechanism of action of IFNT on luteal tissue (Bott et al., 2010; Antoniazzi et al., 2013). Luteal cells ISG15 mRNA expression increased in response to recombinant ovine (Antoniazzi et al., 2013) or bovine (Shirasuna et al., 2015) IFNT in a dose-dependent manner, up to $1 \mathrm{ng} / \mathrm{ml}$. In our study, mixed luteal cell culture presented a dose-dependent response of ISG15 expression after the exposure to IFNA (Fig. 2A). The treatments of luteal cells with CM from embryos on Days 7,9 and 12 had a similar pattern of expression of ISG15 compared to those observed in the IFNA-treated cells. Based on that, our results reveal IFN-like response of luteal cells when exposed to CM from PA embryos, and this evidence was based on ISG15 expression. Besides, it was also observed the longer the embryo develops in vitro the greater IFN activity is detected (Figure 1). This suggests that the expression of ISG15 in luteal cells is dependent on embryo-derived IFNs.

Parthenogenetic activation is used for research purposes to study several events at the moment of early embryonic development (Soloy et al., 1997). On human embryos, parthenogenesis is a source of embryonic stem cells used as a model in several studies, due to religious, ethical, legal and political concerns that are raised when working with embryos capable of generating human life (Brevini and Gandolfi, 2008). Parthenogenetic embryos are derived from a single egg developed without spermatic fertilization (Henery and Kaufman, 1992). Oocytes in the metaphase 2 are activated by ionomicyn (mimicking the calcium wave induced by sperm penetration in the zona pelucida; Henery and Kaufman, 1992) followed by exposure to an actin polymerization inhibitor, usually cytochalasin B, originating diploid parthenotes (Bałakier and Tarkowski, 1976). These PA embryos begin to express IFNT mRNA on the blastocyst phase at day 6 and the expression levels of IFNT mRNA was not different among in vitro fertilized (IVF), somatic cell nuclear transfer (NT) and PA embryos on Day 7 (Yao et al., 2009). In our study, IFNT mRNA was not assessed. However, the antiviral assay detected Type I IFN activity in CM from Days 7, 9 and 12 of embryo development, with greater activity on Days 9 and 12 . Furthermore, the mRNA expression of ISG15 was not different on Days 7,9 and 12, although these days were greater when compared to control group (Fig. 2B). The results presented herein suggest the Type I IFN activity detected on the antiviral assay may be from PA embryoderived IFNT.

Interferon A and IFNT are Type I interferons, having similar three-dimensional structure (Roberts et al., 1999) and analogous biological activities such as recognition of common classes of cell surface receptors (Mogensen et al., 1999). The IFNA is more cytotoxic in Madin-Darby bovine kidney (MDBK) cell line than IFNT, but both have similar antiviral activity (Subramaniam et al., 1995). Furthermore, IFNT was shown to be more antiluteolytic than IFNA, maintaining high plasma progesterone concentration for longer periods after estrus in ewes (Green et al., 2005). Due to the similarity between IFNT and IFNA, and because the recombinant bovine IFNT is not yet commercially available, IFNA was used in our study as a positive control to validate the responsiveness of luteal cells based on their ability to express ISG15 mRNA in response to Type I interferon. In another study, luteal cell culture treated with recombinant ovine IFNT reached the plateau of ISG15 mRNA expression at $1 \mathrm{ng} / \mathrm{ml}$ (Antoniazzi et al., 2013). However, when treated with IFNA, the plateau was reached at $10 \mathrm{ng} / \mathrm{ml}$, as expected, because IFNA effects on luteal cells are reduced when compared to IFNT (Green et al., 2005).

Progesterone is a steroid hormone secreted by large and small luteal cells (Niswender, 2002), which prevents luteolysis, regulates the growth and elongation of the blastocyst and the trophoblast secretion and maintenance of IFNT concentrations during the early pregnancy recognition and establishment (Mann and Lamming, 2001). The steroidogenic enzymes cytochrome P450 cholesterol side chain cleavage (P450scc/CYP11A1) converts cholesterol to pregnenolone (Niswender, 2002), and then 3 $\beta$-hydroxysteroid dehydrogenase (3 $\beta$-HSD) converts pregnenolone to progesterone in the smooth endoplasmic reticulum (Niswender, 2002). Luteal cell culture treated with 0.1 or $1 \mathrm{ng} / \mathrm{ml}$ IFNT did not change progesterone secretion (Shirasuna et al., 2015). Ewes infused with BSA or recombinant ovine (ro) IFNT did not alter progesterone concentrations in serum (Antoniazzi et al., 2013). Both ovine IFNA and IFNT did not change plasma progesterone concentrations when infused in nonpregnant ewes in the same period (Green et al., 2005). In our results, progesterone concentrations were not different in the culture medium of mixed luteal cells treated with CM or IFNA (Tab. 2). Besides that, CYP11A1 and HSD3B1 mRNA expression were similar in all embryonic developmental days, in the different treatments with IFNA and the control. This confirms that neither CM nor IFNA stimulate progesterone secretion in luteal cells.

Bcl-2 family of proteins are involved in the regulation of apoptosis. Some members, as the Bcl-2, are antiapoptotic, while BAX is proapoptotic (Adams and Cory, 1998). The serine/threonine kinase (AKT) or protein kinase $\mathrm{B}$ (PKB) contributes to the diverse cellular roles such as cell survival, growth, proliferation, angiogenesis, metabolism, and migration (Manning and Cantley, 2007). XIAP (X-linked inhibitor of apoptosis) is a member of the inhibitor of apoptosis proteins (IAPs) family, and acts as an antiapoptotic molecules to inhibit the activity of some caspases, such as caspases 3 and caspases 7 (Takahashi et al., 1998). Ewes infused with BSA and roIFNT did not present differences in luteal $A K T$ mRNA expression, but increased XIAP mRNA in 
the roIFNT-infused group (Antoniazzi et al., 2013). Luteal cell culture treated with CM on Days 7, 9 and 12 did not change $B A X, B C L 2, A K T$ and XIAP mRNA expression when compared to the control group (Fig. 4CF). Luteal cell culture treated with IFNA did not change cell survival genes expression (Fig. 3C-F), demonstrating that IFNA does not regulate cell survival/apoptosis of in vitro cultured luteal cells.

In conclusion, findings of the present study support the hypothesis that luteal cell culture increase ISG15 mRNA expression when treated with PA CM, which present Type I IFN activity. This antiviral activity present on CM from PA embryos may be from IFNT. Furthermore, luteal cell culture maintains progesterone secretion and no difference were observed on steroidogenic genes, suggesting the culture system was well established. Taken these together, CM from PA embryo culture present antiviral activity, luteal cells respond to Type I interferon and express ISG15. Finally, luteal cell culture is a valid system to evaluate Type I interferon response. These data indicate this model can be useful for IFNT endocrine signaling studies.

\section{Acknowledgments}

The authors thank the Biotechnology and Animal Reproduction Laboratory students for assistance with laboratorial procedures and the Virology Sector for the antiviral assay. to disclose.

Disclosure statement: The authors have nothing

\section{References}

Adams JM, Cory S. 1998. The Bcl-2 protein family: arbiters of cell survival. Science, 281:1322-1326.

Antoniazzi AQ, Webb BT, Romero JJ, Ashley RL, Smirnova NP, Henkes LE, Bott RC, Oliveira JF, Niswende, GD, Bazer FW, Hansen TR. 2013 Endocrine delivery of interferon tau protects the corpus luteum from prostaglandin F2 alpha-induced luteolysis in ewes. Biol Reprod, 88:144.

Austin KJ, Ward SK, Teixeira MG, Dean VC, Moore DW, Hansen TR. 1996. Ubiquitin cross-reactive protein is released by the bovine uterus in response to interferon during early pregnancy. Biol Reprod, 54:600-606.

Austin KJ, Bany BM, Belden EL, Rempel LA, Cross JC, Hansen TR. 2003. Interferon-Stimulated Gene-15 (Isg15) Expression Is Up-Regulated in the Mouse Uterus in Response to the Implanting Conceptus. Endocrinology, 144:3107-3113.

Austin KJ, Carr AL, Pru JK, Hearne CE, George EL, Belden EL, Hansen TR. 2004. Localization of ISG15 and Conjugated Proteins in Bovine Endometrium Using Immunohistochemistry and Electron Microscopy. Endocrinology, 145, 967:975.

Balakier H, Tarkowski AK. 1976. Diploid parthenogenetic mouse embryos produced by heat-shock and Cytochalasin B. J Embryol Exp Morphol, 35:25-39.

Bebington C, Doherty FJ, Fleming SD. 1999. Ubiquitin cross-reactive protein gene expression is increased in decidualized endometrial stromal cells at the initiation of pregnancy. Mol Hum Reprod, 5:966-972.

Bott RC, Ashley RL, Henkes LE, Antoniazzi AQ, Bruemmer JE, Niswender GD, Bazer FW, Spencer TE, Smirnova NP, Anthony RV, Hansen TR. 2010. Uterine vein infusion of interferon tau (IFNT) extends luteal life span in ewes. Biol Reprod, 82:725-735.

Brevini TAL, Gandolfi F. 2008. Parthenotes as a source of embryonic stem cells. Cell Proliferation, 41:20-30.

Gifford CA, Racicot K, Clark DS, Austin KJ, Hansen TR, Lucy MC, Davies CJ, Ott TL. 2007. Regulation of Interferon-Stimulated Genes in Peripheral Blood Leukocytes in Pregnant and Bred, Nonpregnant Dairy Cows. J Dairy Sci, 90:274-280.

Green MP, Spate LD, Bixby JA, Ealy AD, Roberts RM. 2005. A Comparison of the Anti-Luteolytic Activities of Recombinant Ovine Interferon-Alpha and Tau in Sheep. Biol Reprod, 73:1087-1093.

Haas AL, Ahrens P, Bright PM, Ankel H. 1987. Interferon induces a 15-kilodalton protein exhibiting marked homology to ubiquitin. J Biol Chem, 262:1131511323.

Han H, Austin KJ, Rempel LA, Hansen TR. 2006. Low blood ISG15 mRNA and progesterone levels are predictive of non-pregnant dairy cows. J Endocrinol, 191:505-512.

Henery CC, Kaufman MH. 1992. Cleavage rate of haploid and diploid parthenogenetic mouse embryos during the preimplantation period. Mol Reprod Dev, 31:258-263.

Imakawa K, Anthony RV, Kazemi M, Marotti KR, Polites HG, Roberts RM. 1987. Interferon-like sequence of ovine trophoblast protein secreted by embryonic trophectoderm. Nature, 330:377-379.

Loeb KR, Haas AL. 1992. The interferon-inducible 15$\mathrm{kDa}$ ubiquitin homolog conjugates to intracellular proteins. J Biol Chem, 267:7806-7813.

Mann G, Lamming G. 2001. Relationship between maternal endocrine environment, early embryo development and inhibition of the luteolytic mechanism in cows. Reproduction, 121:175-180.

Manning BD, Cantley LC. 2007. AKT/PKB Signaling: Navigating Downstream. Cell, 129:1261-1274.

Méo SC, Yamazaki W, Ferreira CR, Perecin F, Saraiva NZ, Leal CLV, Garcia JM. 2007. Parthenogenetic activation of bovine oocytes using single and combined strontium, ionomycin and 6dimethylaminopurine treatments. Zygote, 15:295-306.

Miyamoto Y, Skarzynski DJ, Okuda K. 2000. Is Tumor Necrosis Factor $\alpha$ a Trigger for the Initiation of Endometrial Prostaglandin F2 $\alpha$ Release at Luteolysis in Cattle? Biol Reprod, 62:1109-1115.

Mogensen KE, Lewerenz M, Reboul J, Lutfalla G, Uzé G. 1999. The Type I Interferon Receptor: Structure, Function, and Evolution of a Family Business. $J$ Interferon Cytokine Res, 19:1069-1098.

Narasimhan J, Potter JL, Haas AL. 1996. Conjugation of the $15-\mathrm{kDa}$ Interferon-induced Ubiquitin Homolog Is Distinct from That of Ubiquitin. J Biol Chem, 271:324330.

Niswender G. 2002. Molecular control of luteal secretion of progesterone. Reproduction, 123:333-339.

Oliveira JF, Henkes LE, Ashley RL, Purcell SH, 
Smirnova NP, Veeramachaneni DN, Anthony RV, Hansen TR. 2008. Expression of interferon (IFN)stimulated genes in extrauterine tissues during early pregnancy in sheep is the consequence of endocrine IFNtau release from the uterine vein. Endocrinology, 149:1252-1259.

Roberts RM, Chen Y, Ezashi T, Walker AM. 2008. Interferons and the maternal-conceptus dialog in mammals. Semin Cell Dev Biol, 19:170-177.

Roberts RM, Ealy AD, Alexenko AP, Han CS, Ezashi T. 1999. Trophoblast Interferons. Placenta, 20:259-264.

Shirasuna K, Matsumoto H, Matsuyama S, Kimura K, Bollwein H, Miyamoto A. 2015. Possible role of interferon tau on the bovine corpus luteum and neutrophils during the early pregnancy. Reproduction, 150:217-225.

Soloy E, Kanka J, Viuff D, Smith SD, Callesen H, Greve T. 1997. Time course of pronuclear deoxyribonucleic acid synthesis in parthenogenetically activated bovine oocytes. Biol Reprod, 57:27-35.

Subramaniam PS, Khan SA, Pontzer CH, Johnson
HM. 1995. Differential recognition of the type I interferon receptor by interferons tau and alpha is responsible for their disparate cytotoxicities. Proc Natl Acad Sci U S A, 92:12270-12274.

Takahashi R, Deveraux Q, Tamm I, Welsh K, AssaMunt N, Salvesen GS, Reed JC. 1998. A Single BIR Domain of XIAP Sufficient for Inhibiting Caspases. Journal of Biological Chemistry 273, 7787-7790.

Thatcher WW, Guzeloglu A, Mattos R, Binelli M, Hansen TR, Pru JK. 2001. Uterine-conceptus interactions and reproductive failure in cattle. Theriogenology, 56:1435-1450.

Vogel SN, Friedman RM, Hogan MM. 2001. Measurement of Antiviral Activity Induced by Interferons $\alpha, \beta$, and. Curr Protoc Immunol, Chapter 6:Unit 69.

Yao N, Wan PC, Hao ZD, Gao FF, Yang L, Cui MS, Wu Y, Liu JH, Liu S, Chen H, Zeng SM. 2009. Expression of Interferon-tau mRNA in Bovine Embryos Derived from Different Procedures. Reprod Dom Anim, 44:132-139. 